\title{
Disability Due to Leprosy Diseases and Community Experience at Kampung Kusta Sitanala Tangerang Banten in The Context of Urban People
}

\author{
Nuah Perdamenta Tarigan \\ Bina Nusantara University: Character Building Development Centre (CBDC) \\ Gerakan Peduli Disabilitas dan Lepra Indonesia (GPDLI) Jakarta, Indonesia nuah.tarigan@ binus.ac.id
}

\begin{abstract}
Sitanala leprosy village is a spontaneously established village of "kusta" patients (leprosy or morbus hansen) from the Sitanala leprosy hospital located in Tangerang Banten. Its location not far from the airport Soekarno Hatta promising an interesting prospect for Local Government to change the location of the leprosy residence from there to become a business center. The burden of leprosy stigma is still very high, even in areas called "low endemic". Both individuals, families and communities experience painful effects. In the context of the world's most populous Muslim country, leprosy in Indonesia is a challenge, it needs a greater movement within the community to build leprosy communities more empowered..All the way taken, but the crucial problem of stigma and discrimination against leprosy has not been resolved until now in Indonesia.

Keywords: leprosy, stigma, discrimination
\end{abstract}

\section{INTRODUCTION}

Leprosy is still a lot in Stigma and Discrimination! there needs to be a fundamental change-starting with formal and informal education! People who have leprosy in Indonesia have long experienced discrimination, even in isolated since hundreds of years ago all over the world including in Indonesia. Until now there are still leprosy settlements such as Leprosy Village in Sitanala, Tangerang, Banten Province. In a study undertaken to understand the conditions of settlements of people affected by leprosy in 17 villages in 13 provinces, it was found that most of these settlements are located in urban and rural areas that have poor public facilities such as education and health services, whereas most of these villages are still managed by the state [1]. In addition, very few of these settlements have ever received community development assistance funds that empower them. Interviews of residents also revealed that in addition to low education, many still do not have a permanent job. They admit that it is difficult to develop themselves and their abilities because they are rejected by the family and society [2]. Ministry of Health research in 2008 found the same thing (Sihombing, 2008) at that time the leader of GPDLI (Movement for Disability and Leprosy of Indonesia) has initiated research for some leprosy villages in Indonesia, covering the islands of Sumatra, Java, Kalimantan, Sulawesi, NTT and Papua and others funded by an Institution from Japan.

This short story can tell how the situation in one of the big cities of leprosy in Jakarta, one day at the home of Mr Yatmo and Mrs. Sriyatmo cheerful to see the children who studied at home for a long time, GPDLI see this need and finally start cooperating with the organization others in facilitating and assisting this leprosy community. Feedback on a media social called Facebook on December 6, 2011 made many people moved to contribute. Touched by the number of small children begging on the streets with their parents, Ibu Sriyatmo finally has a desire to form a Rumah Belajar (house of learning) nearby Mosque of Rachmi Hatta in the village of Leprosy SITANALA Tangerang Banten, home of a small size $13.5 \mathrm{x}$ $12 \mathrm{~m} 2$ owned by Mr and Mrs. Yatmo accommodate children who studied there since a few years ago, almost every day the house enlivened with children who learn after school, and have the spirit of learning for their future. Dutasia Foundation through its facilitators, trying to jointly build the future of these children, especially in the field of education. The Disability and Leprosy Indonesia Care Movement (GPDLI), chaired by Mr. Herman Hutabarat and friends in the field, has been also keen to collaborate in building the overall progress of the community around the village of Sitanala leprosy, located not far from Soekarno Hatta international airport. With the increasing number of children in attendance, making the room around Ibu Sri's house ( $8 \times 2 \mathrm{~m}$ front porch) is not possible to be used again effectively, so it has been built at this time the room beside the $6 \times 12$ size building for bigger place, Rumah Belajar is used for joint study, Taman Bacaan (a small library) and Bengkel Seni (Art Studio) as well as a place to develop leprosy community groups in art-culture and empowerment such as microfinance / savings and borrowing and trainings such as computers and sewing and others.

\section{LITERATURE REVIEW}

Sitanala is a leprosy community located in the middle of the city Tangerang has a long history, starting from a hospital formerly called the Sitanala leprosy hospital, to have a leprosy settlement located beside the location of the hospital. The change took place a few years ago so that the word term that indicates the leprosy hospital changed only into a public hospital. This change occurs not only from the national but global but the researchers see that stigma and discrimination are not a bit, one of the most painful is the separation of care between the general patient and the patient who has had leprosy. 
One of the disability and leprosy agencies working continuously eliminating the stigma and discrimination there is the Disability and Leprosy Care Movement Indonesia (GPDLI). One of the leaders who had lived in the village of leprosy and many others experienced directly in the field of stigma and discrimination, not from outsiders Sitanala complex, but directly from the workers and Sitanala hospital institutionally.

Indonesia especially Jakarta Bogor Tangerang Depok Bekasi (Jabodetabek) as a metropolitan city and tend to be categorized as megapolitan city that has a socio-economic and political problems are very large in Indonesia. (GPDLI)/ Indonesia Leprosy and Disability Care Movement was established in 2009 to become a bridge and grass roots disability and people affected by leprosy organization : "to connect communities and individuals, such as among others local pioneers and champions, local-, national- and international NGOs like NLR (an International NGO from Holland), CSO, DPOs, local, national- and international universities and researchers, local and national governmental departments, businesses, companies with a Corporate Social Responsibility (CSR) program provided by companies and universities such TFI (Teach For Indonesia) and Bina Nusantara University (Binus) and many entrepreneurs in Indonesia.[3] GPDLI, as a disable people organization and network organization, has taken up the role of initiator and facilitator of collaborations and partnerships between all stakeholders involved in efforts for the sustainable development of People Affected by leprosy and disability among them. Not just an idea or ideology, the members and supporters of GPDLI have a sincere desire to improve the wellbeing of people on Indonesia based on human rights, empowerment, green and fair principles. "Collective impact" is the basic principle of the network as "No single organization is responsible for any major social problem, nor can any single organization cure it." Moreover, not single projects or events but sustainable synchronized activities are viewed as alternatives for developments on Indonesia especially Jabodetabek. The intent and purpose of this GPDLI are: (Vision Strategy):

1. Restoring and saturating self-confidence for People who have had Leprosy and Its disability/ other disabilities

2. Removing negative stigma experienced among People with Disabilities and Leprosy/other disabilities

3. Empowering people who have had leprosy (People Affected by Leprosy) and their surrounding communities in building better future starting from their personal situation and then their family and community/society.

In short people from "all walks of life", who are all engaged and committed in their own professional as well as personal way to support the development of People Affected by Leprosy and People with Disability. Looking at the situation that is still not profitable for the marginal community of Indonesia at this time then we think there are some things that can be a good consideration to lead to the good:
1. Building a new paradigm for the new social movement organization that based its movement not only on the context of rights but also its obligation as an Indonesian citizen.

2. Explore the main problems arising from the relationship between persons with disabilities and the wider community, between them and members of civil society.

3. Establish a clear and open Goal Vision, Mission, and Goal Setting, through a participatory approach.

4. Propose a forum of joint network organizations relevant to the contemporary context of persons with disabilities without leaving their respective umbrella organizations in carrying their specific problem situation.

5. Realizing a forum that elects candidates for legislators, or who may work in the executive and judiciary, as well as other relevant state institutions.

6. Build a continuous cadre of organizations until a shared vision is achieved.

7. Works in a synergistic, transparent and full of courage.

8. Undoubtedly what is aspired together will gain blessings and divine grace so that there will be a paradigm transformation within the disability community and Indonesian civil society (Tarigan, 2011). The other important meeting besides above event was a facilitation training for GPDLI for CRPD issues (Convention of Rights for Person with Disabilities in 2015 which then developing a The Jakarta Consensus (7th February 2015) at Wisma PGI Jakarta (Meeting supported by Disability Rights Fund) with three statements as below:

A. Government (Executive, Legislative, Judicial) National / Regional, should pay attention to People who have disabilities and leprosy better by giving access to an open, accurate, transparent and responsive in all aspects!

B. The government sector, private sector and the public should be able to create jobs and entrepreneurial field and job training and skills for people with disabilities / leprosy, their families and communities so as not to cause social and economic problems are even greater!

C. Must be included in any process of planning, preparation and supervision of government and private programs and community development in strategic planning as well as to guard them in the development of future society, No Stigma and Discrimination! With the persons who declare this stamen as follow: Amir Alrafati, Anggih Ardiyani, Hermen M. Hutabarat; Ismail; Ita Siti Fatimah; Nuah P. Tarigan; Robi Darmawan; Yatmo; Sri Yatmo; Maulani Rotinsulu.

\section{METHODS}

The research used is a qualitative research that is widely used in the branch of social science such as research that focuses on the development of character in building a leprosy community entitled Disability Due To Leprosy Diseases And Community Experience At Kampung Kusta Sitanala Tangerang Banten In The Context Of Urban People, conducted in this study takes the viewpoint of the observer's results on the basis of data collection and interpretation through direct contact in the field (Creswell JW, 2007). Therefore, this qualitative research relies 
heavily on the researcher himself in understanding, describe, interpret, and explain all the things and information available. Qualitative research is also called constructive, naturalist or interpretative approach. Qualitative research emphasizes the understanding of problems in social life based on reality on natural setting [4].

\section{RESULT AND DISCUSSION}

The results we get from this research are: review and update of outcomes to date in community especially Sitanala and beyond, with the exciting developments related to our collaboration with Binus University for 5 years, and NLR for 2-3 years, participants share experiences, results (success and failures) and information to move forward, identification of new opportunities for collaboration among stakeholders, as well as opportunities for business and inclusive business models. Possible start-up of a social entrepreneurship model or Creative and Agricultural activities or maybe employment possibilities in the region and the short and mid-long-term action plans and commitments implementation by GPDLI network members including Binus University and NLR as well as the local governments. There was not only the empowerment of the person with disabilities but also a facilitation of these person on how to understand their equal rights for their own future from DRF (Disability Rights Fund). GPDLI as operator for this facilitation and FARHAN organization which coordinating people affected by leprosy in Indonesia besides other organizations who developing leprosy in Indonesia as the result of The Jakarta Consensus meeting with Indonesia Human Rights Commissioners in Jakarta.

\section{CONCLUSIONS}

In accordance with the title of this paper "Disability Due To Leprosy Diseases And Community Experience At Kampung "Kusta" Sitanala Tangerang Banten In The Context Of The Urban People" which is related to live portrait of life and community empowerment of the two aspects above that is leprosy and disability can be taken conclusion that leprosy is not only related to health problems but also affects their social social problems which ultimately have a direct impact on their livelihoods, if there is no breaking of the poverty cycle then people affected by leprosy and disability within the Sitanala community will continue to receive marginalization in their lives. The resonance of this movement in the future is not a small thing because all civil society members will increasingly realize that Government, Institutions, Companies, Communities, Universities and School Schools can become a significant transformation base in the development of our beloved Indonesia, Nation Character Building Indonesia that has been declared the Fathers of our nation since decades ago. Respect all elements of the nation regardless of the situation and background in-order to be benefit of our nation, especially those who are marginalized.[5] Well-established relationships can make this relationship a sustainability movement in the future, especially in the vision of developing and realizing a community that has a better quality of life holistically.
Justice that has not existed and is apparent among the disabilities in Indonesia especially people affected by leprosy is very large and spread in the archipelago is very large, making the issue of equality is a very important thing especially with the publication of the Disability Act No. 8 of 2016 at the beginning of that year. Only a few provinces that understand properly and well on open and potential issues and issues will affect other areas including the increasingly growing number of elderly people in Indonesia due to the increasing welfare of the people. The government of DKI Jakarta (in the era of Jokowi and Ahok/ Djarot), including the most concerned with disability, from the beginning has set a bold step to defend things related to disability, including local governments in Solo, Bali, Makassar and several other areas. Leprosy belonging to the disability community has a very tough marginalization, the disability that arises from leprosy quite a lot, reaches ten percent more and covers the poor areas of Indonesia, such as Nusa Tenggara Timur, Papua, South Sulawesi Provinces and even East Java and West Java and Central Java Provinces. If we compare again with the ASEAN countries we also do not miss the moment in ratifying the CRPD (Convention of Rights for People with Disability) into the Law of Disability No. 8 of 2016 which, although already published but still get rejections in some sections because do not provide proper empowerment and rights equality. The struggle is long and must be continued to build equal rights in all areas, not only health and welfare but also in the right of the right to receive continuous inclusive education.

\section{ACKNOWLEDGMENT}

This article was submitted and presented in the event INTERNATIONAL CONFERENCE 2017 DIVERSITY AND DISABILITY INCLUSION IN MUSLIM SOCIETIES: EXPERIENCES FROM ASIA at Hotel Grandhika Iskandarsyah, Kebayoran Baru, Jakarta Selatan Jakarta, 21 22 November 2017.

\section{REFERENCES}

[1] N. Tarigan, Kusta Siapa Takut. YTLI, 2008.

[2] N. Tarigan and K. Pandiangan, "Leprosy Who Aftraid. Tarigan, Nuah and Pandiangan, Kris (2008). Research on Indonesia Leprosy Villages," Res. Indones. Lepr. Village, 2008.

[3] M. R. Nindita Radyati, Sustainable Business dan Corporate Social Responsibility (CSR). Jakarta, Indonesia.: Triasakti University, 2014.

[4] Sugiarto, Metodologi Penelitian Hospitaliti dan Parawisata. 2015.

[5] M. R. Nindita Radyati, Organisational Governance Based On ISO 26000: A Tool Box. Jakarta, Indonesia.: Triasakti University, 2015. 